\title{
A systematic review of the burden and risk factors of sudden infant death syndrome (SIDS) in Africa
}

\author{
Godwin K Osei-Poku' ${ }^{1}$ \\ Sanya Thomas ${ }^{1}$, Lawrence \\ Mwananyanda ${ }^{1,2}$, Rotem \\ Lapidot $^{3,4}$, Patricia A Elliott ${ }^{5}$, \\ William B Macleod ${ }^{1}$, Somwe \\ Wa Somwe ${ }^{6}$, Christopher J Gill ${ }^{1}$ \\ ${ }^{1}$ Boston University School of Public \\ Health, Department of Global Health, \\ Boston, Massachusetts, USA \\ ${ }^{2}$ Right to Care - Zambia, Lusaka, Zambia \\ ${ }^{3}$ Boston University School of Medicine, \\ Department of Pediatrics, Boston, \\ Massachusetts, USA \\ ${ }^{4}$ Boston Medical Center, Division \\ of Pediatric Infectious Diseases, \\ Department of Pediatrics, Boston, \\ Massachusetts, USA \\ ${ }^{5}$ Boston University School of Public \\ Health, Department of Community \\ Health, Boston, Massachusetts, USA \\ ${ }^{6}$ University of Zambia, School of \\ Medicine, Department of Pediatrics, \\ Lusaka, Zambia
}

\section{Correspondence to:}

Godwin K. Osei-Poku, MD, MPH Department of Global Health Boston University School of Public Health 801 Massachusetts Avenue Boston, MA 02118 USA

opkg2013@bu.edu
Background While sudden infant death syndrome (SIDS) has long been recognized as a leading preventable cause of infant mortality in high-income countries, little is known about the burden of SIDS in Africa. To address this knowledge gap, we conducted the first systematic review of SIDS-related publications in Africa. Our objective was to assess the prevalence of SIDS and its risk factors in Africa.

Methods We systematically searched PubMed, Embase, Web of Science, Cochrane, and Google Scholar to identify studies published until December 26, 2020. Review authors screened titles and abstracts, and selected articles independently for full-text review. Risk of bias was assessed using the Newcastle Ottawa Scale (NOS) or a modification. Data on the proportion of infants who died of SIDS and reported prevalence of any risk factors were extracted using customized data extraction forms in Covidence.

Results Our analysis rested on 32 peer-reviewed articles. Nine studies presented prevalence estimates on bedsharing and prone sleeping, suggesting near-universal bedsharing of infants with parents (range, 60 to $91.8 \%$ ) and frequent use of the prone sleeping position (range, 26.7 to 63.8\%). Eleven studies reported on the prevalence of SIDS, suggesting high rates of SIDS in Africa. The prevalence of SIDS ranged from 3.7 per 1000 live births in South Africa, 2.5 per 1000 live births in Niger, and 0.2 per 1000 live births in Zimbabwe. SIDS and other sudden infant deaths accounted for between 2.5 to $21 \%$ of infant deaths in South Africa and $11.3 \%$ in Zambia.

Conclusions Africa may have the highest global rate of SIDS with a high burden of associated risk factors. However, majority of the studies were from South Africa which limits generalizability of our findings to the entire continent. There is an urgent need for higher quality studies outside of South Africa to fill this knowledge gap.

Protocol registration Prospero Registration Number: CRD42021257261

In wealthier countries, sudden infant death syndrome (SIDS), a subset of sudden unexpected infant death (SUID), is recognized as a leading preventable cause of infant mortality. According to the US Centers for Disease Control and Prevention (CDC), SIDS was the leading cause of post-neonatal mortality and the fourth leading cause of infant mortality in the United States in 2017 [1]. SIDS is "the sudden and unexpected death of an infant under 12 months of age that remains unexplained after a review of the clinical history, complete autopsy and death scene investigation, with 
the onset of the fatal episode occurring during sleep" [2,3]. Nearly 90 percent of SIDS cases occur between birth and six months of age with a peak incidence around two to four months [4,5]. And while the pathobiology of SIDS may involve genetic or developmental factors, a key event in many SIDS cases is some form of respiratory stress, culminating in accidental suffocation. This is a critical point to note since the interventions that have successfully reduced SIDS deaths in the US and similar settings have largely focused on changes in infant sleeping conditions, most notably having infants sleep on their backs.

Sleeping in the prone or side position and bedsharing are recognized as major risk factors of SIDS [6]. The risk of re-breathing expired gases is increased in the prone or side sleeping position leading to hypoxia or hypercapnia [7]. Bedsharing is also important in suffocation deaths due to being accidentally rolled on by a sleeping adult. Infections and genetic polymorphisms have also been suggested in the etiology of SIDS [8,9]. Since symptoms of infectious diseases can be subtle in infants and hence not recognized ante-mortem, much attention has focused on the post-mortem identification of infectious pathogens. Multiple SIDS deaths in one family may also suggest a genetic link in the etiology of SIDS [10]. Other risk factors include little or no prenatal care, maternal age less than 20 years, prematurity or low birth weight, and maternal use of alcohol or smoking during pregnancy [11-14].

In sub-Saharan Africa, the contribution of SIDS to infant mortality has not been well understood. Very few studies have tried to estimate the incidence or prevalence of SIDS in Africa [15], and even fewer have studied the risk factors of SIDS [16]. Given the paucity of published studies on SIDS/SUID in Africa, this cause of child mortality has not been viewed as a high priority and has largely been ignored. And yet there is no reason to believe that SIDS is not a problem in African populations as it has been wherever else SIDS has been studied. Prior systematic reviews have used data from studies performed in high-income countries [17]. To the best of our knowledge, no systematic review has focused on SIDS/SUID in Africa.

To fill this knowledge gap, we conducted a systematic review of SIDS/SUID studies conducted in Africa. Our review focused on two main questions:

1. What is the prevalence of known and hypothesized risk factors of SIDS/SUID in Africa?

2. What is the burden of SIDS and/or SUID deaths in Africa?

\section{METHODS}

\section{Database and hand searching}

PubMed, Embase, Web of Science, Cochrane, and Google Scholar were searched with search terms developed in collaboration with a librarian. The PubMed search was developed first using the following search terms: (" "Sudden Infant Death"[Mesh] OR "Sudden Infant Death Syndrome" OR "SIDS" OR "Sudden Infant Death" OR "Sudden Unexpected Infant Death" OR "Cot Death" OR "Cot Deaths" OR "Crib Death" OR "Crib Deaths" OR "Accidental Suffocation" OR "Unintentional Suffocation" OR "Strangulation in Bed" OR "ASSB")) and an African search filter previously developed by Pienaar et al [18] (Appendix S1 in the Online Supplementary Document).

All articles up to December 26, 2020 (the date on which the search was executed) were included. There was no prior date restriction on the search. All returned articles were then imported into Covidence (Covidence. org, Melbourne, Australia, https://www.covidence.org), a systematic review software, for screening and data extraction. Duplicate articles were removed using the de-duplication feature in Covidence. Duplicate articles that were missed in this initial phase were removed during full-text review manually by the review authors.

\section{Selection process}

Two review authors (GKO-P and ST) independently screened titles and abstracts to identify any relevant articles. Articles that passed this initial review were included in a full-text review. The full texts of included studies were then screened. Articles that met the inclusion criteria were included in the review. Disagreements were resolved through discussion between reviewers until consensus was reached.

\section{Inclusion/exclusion criteria}

Articles were included for review if they met the following inclusion criteria:

- Original research articles, case reports, and case series were included. Editorials, letters to the editor, opinions, and review articles were excluded. 
- Articles were restricted geographically to Africa (including North Africa and sub-Saharan Africa).

- Non-English language articles were included if an English translation was available or if it could be translated into English using Google Translate.

- Articles that specifically mentioned or reported data on Sudden Unexpected Infant Death (SUID) or Sudden Infant Death Syndrome (SIDS) (known or hypothesized risk factors or burden of disease) were included. Articles that reported on a population that included infants but were not necessarily limited to infants were included if they reported on the prevalence of SIDS/SUID in the cohort of infants.

\section{Data collection and analysis}

We independently extracted the following data using customized data extraction forms in Covidence: author and institutional affiliation, source of funding and conflict of interest, year of publication, study design, study aim, country of the population studied, sample size including total number of infants studied, number and proportion of infants who died of SIDS and/or SUID, and reported prevalence of any risk factors.

We independently assessed risk of bias for each included study using the Newcastle Ottawa Scale for observational studies [19] or a modification [20-23]. Case-control and cohort studies were assessed on three main domains of selection, comparability, and ascertainment of exposure and outcome. For case reports/case series studies, we excluded items on comparability and adjustment since these studies were non-comparable [2022]. We assessed cross-sectional/prevalence studies on representativeness of the sample and size, comparability between respondents in different outcome groups, and appropriateness and completeness of the statistical test/analysis [23].

We did not receive nor require ethical approval for this study, as it does not involve human and animal subjects.

Prospero Registration Number: CRD42021257261 (Protocol available here: https://www.crd.york.ac.uk/ prospero/display_record.php?RecordID=257261)

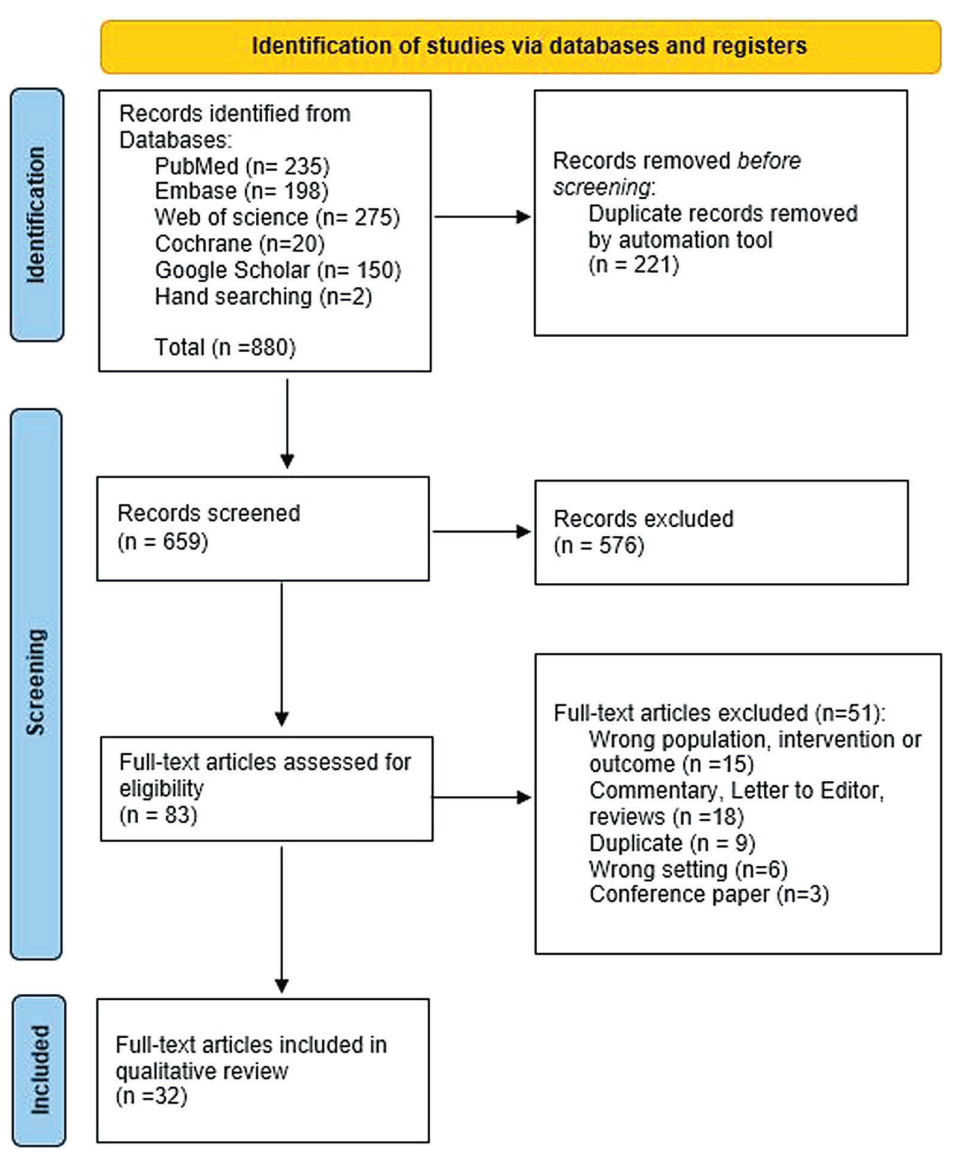

Figure 1. PRISMA flow diagram of search strategy. The PRISMA diagram details our search and selection process during the review. Source: [24]. For more information, visit: http://www.prisma-statement.org/.

\section{RESULTS}

\section{Study characteristics}

Our search yielded 880 articles. 221 were identified as duplicates and were removed by the de-duplication feature in Covidence. The titles and abstracts of 659 articles were then reviewed and 576 were judged to be irrelevant. For example, 67 studies were identified with the acronym SIDS which also refers to Small Island Developing States - these were deemed irrelevant.

The full texts of 83 articles were reviewed and 51 were excluded. These were: commentaries, editorials, and reviews $(n=18)$; studies that reported on the wrong population, exposure, or outcomes $(n=15)$; conference abstracts/papers $(n=3)$; wrong study setting or non-African studies $(\mathrm{n}=6)$; and duplicate articles $(\mathrm{n}=9)$ which were missed using the de-duplication feature in Covidence. Thirty-two full-text articles were included in the final qualitative review/synthesis (25 original studies and 7 case reports/case series). This process is summarized in the PRISMA flow diagram (Figure 1).

\section{Year of publication:}

The included studies were published from 1983 to 2021 (we received the pre-print version of the 2021 article from the study authors in December 2020) with most conducted in the last decade. Sixty-nine percent were published between 2010 and 2021, with the majority in $2018(n=5,16 \%)$ (Figure 2). 


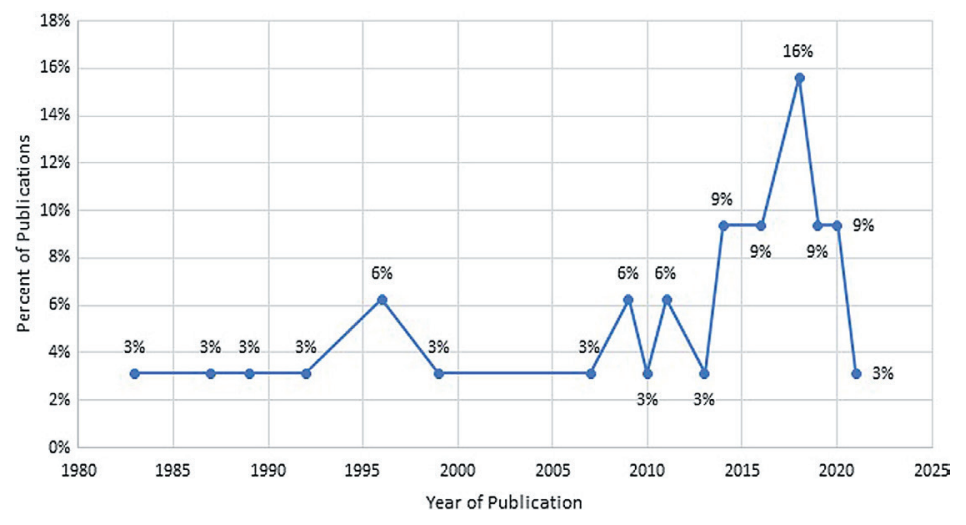

Figure 2. Distribution of included studies by year of publication. The figure shows the distribution of included studies by year of publication. Until recently, SIDS has been a low priority for researchers in Africa. More than half (52\%) of the included studies were published between 2013 and 2021.

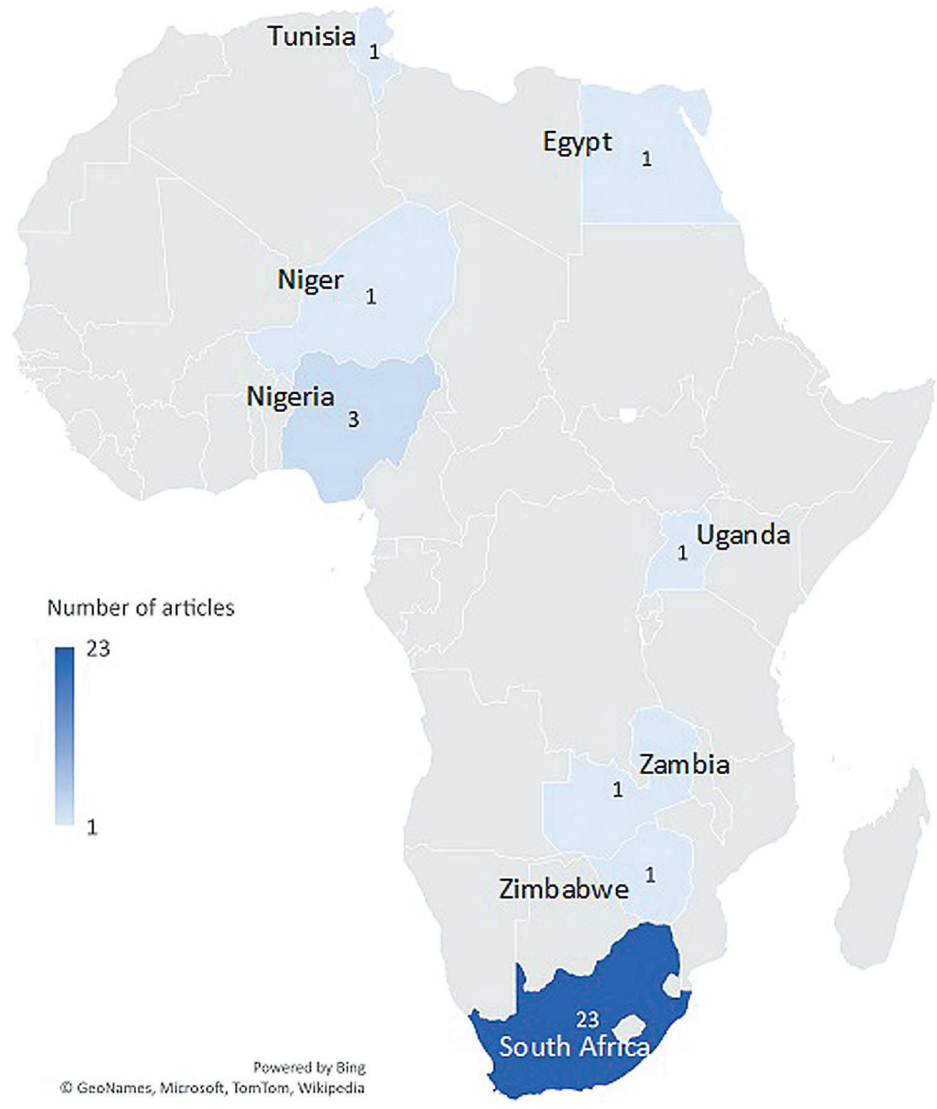

Figure 3. Distribution of included studies across the African continent. The figure shows the distribution of included studies across the African continent. Overall, the studies were skewed to southern Africa with the majority (72\%) from South Africa. Slightly more than a quarter (28\%) of the studies were conducted outside of South Africa.

\section{Geographic distribution of included studies}

Geographically, the articles were skewed to southern Africa ( $\mathrm{n}=25,78 \%)$ with few from west Africa $(\mathrm{n}=4$, $13 \%)$, north Africa (6\%), and east Africa (3\%). The majority and nearly all of those from southern Africa were published in South Africa $(n=23,72 \%)$ with three from Nigeria (9\%) and one each from Egypt, Niger, Tunisia, Uganda, Zambia, and Zimbabwe (Figure 3).

\section{Quality scores}

The 25 original articles were assessed for bias on a 9-point scale and classified as high (8-9), medium (5-7), or low quality (0-4). By study design, four case-control studies and three prospective cohort studies were included in this review. We rated all the case-control studies as medium quality, rated one cohort study as high quality and the remaining two as medium quality (Table 1). Eighteen studies were described as cross-sectional or retrospective/prospective audits. We rated the majority $(67 \%, \mathrm{n}=12)$ of these studies as medium quality (Table 2).

The 7 case reports/case series were assessed for bias on a 5-point scale and rated similarly as high (5), medium (4), or low quality (0-3). Most of the case reports/case series were also rated as medium quality $(57 \%, \mathrm{n}=4)$ as shown in Table 3. Overall, 4 high-quality studies were included in this review.

\section{SIDS awareness}

Awareness of SIDS was low in the general population. Three studies provided data on SIDS awareness, reporting a SIDS awareness rate of between 12.2\% to $44.3 \%[39,45,46]$. Two of these studies were of low quality and one of medium quality. The medium quality study reported that 49 (12.2\%) of respondents claimed to have heard of SIDS but only $5(1.2 \%)$ had good knowledge of SIDS in a survey of 401 mothers of infants in Enugu, Nigeria [46] (Table 4).

\section{Risk factors for SIDS}

\section{Risk factors intrinsic to the infant}

The peak age of SIDS/SUIDS varied across studies. Two medium quality South African studies found the peak age of SIDS/SUIDS deaths to be $1-2$ months $[40,48]$ while another reported a peak age of 2-4 months [37]. Slightly more male than female infants died of SIDS/ SUID $[37,40,48]$. Three medium quality studies, two from South Africa and the other from Uganda, explored prematurity as a risk factor of SIDS. The South African studies reported that $27 \%$ to $40.6 \%$ of SUID cases were preterm $[41,48]$. The Ugandan study found that suspected SIDS was the second leading cause of death in a cohort of preterm infants, accounting for nearly $25 \%$ of all deaths in that cohort [30].

\section{Risk factors intrinsic to the mother}

Six studies provided prevalence estimates on maternal/parental smoking and alcohol use. One medium-quality study reported a $10.2 \%$ prevalence of exposure to tobacco smoke in Nigeria among mothers at a well-baby 
Table 1. Methodological quality scores for case-control and prospective cohort studies*

\begin{tabular}{|c|c|c|c|c|c|c|c|c|c|c|}
\hline \multicolumn{11}{|c|}{ CASE CONTROL STUDIES } \\
\hline Study, Year & Country & $\begin{array}{c}\text { Case } \\
\text { Definition }\end{array}$ & $\begin{array}{c}\text { Represen- } \\
\text { tativeness } \\
\text { of cases }\end{array}$ & $\begin{array}{l}\text { Selection } \\
\text { of controls }\end{array}$ & $\begin{array}{l}\text { Definition } \\
\text { of controls }\end{array}$ & $\begin{array}{l}\text { Compara- } \\
\text { bility of } \\
\text { cases and } \\
\text { controls }\end{array}$ & $\begin{array}{l}\text { Ascertain- } \\
\text { ment of } \\
\text { exposure }\end{array}$ & $\begin{array}{l}\text { Ascertain- } \\
\text { ment of } \\
\text { cases and } \\
\text { controls }\end{array}$ & $\begin{array}{l}\text { Non-re- } \\
\text { sponse rate }\end{array}$ & $\begin{array}{c}\text { Quality } \\
\text { score }\end{array}$ \\
\hline $\begin{array}{l}\text { Molteno, } \\
1989 \text { [25] }\end{array}$ & $\begin{array}{l}\text { South } \\
\text { Africa }\end{array}$ & 1 & 1 & 1 & 1 & 0 & 1 & 1 & 1 & 7 \\
\hline $\begin{array}{l}\text { Belonje, } \\
1996 \text { [26] }\end{array}$ & $\begin{array}{l}\text { South } \\
\text { Africa }\end{array}$ & 1 & 0 & 1 & 0 & 0 & 1 & 1 & 1 & 5 \\
\hline $\begin{array}{l}\text { Gaaloul, } \\
2016 \text { [27] }\end{array}$ & Tunisia & 1 & 0 & 1 & 1 & 0 & 1 & 1 & 0 & 5 \\
\hline $\begin{array}{l}\text { Van Deventer, } \\
2018 \text { [28] }\end{array}$ & $\begin{array}{l}\text { South } \\
\text { Africa }\end{array}$ & 1 & 1 & 1 & 1 & 0 & 1 & 1 & 1 & 7 \\
\hline \multicolumn{11}{|c|}{ PROSPECTIVE COHORT STUDIES: } \\
\hline & Country & $\begin{array}{l}\text { Represen- } \\
\text { tativeness } \\
\text { of cohort }\end{array}$ & $\begin{array}{c}\text { Selection } \\
\text { of non-ex- } \\
\text { posed } \\
\text { cohort }\end{array}$ & $\begin{array}{l}\text { Ascertain- } \\
\text { ment of } \\
\text { exposure }\end{array}$ & $\begin{array}{l}\text { Demon- } \\
\text { stration } \\
\text { that out- } \\
\text { come was } \\
\text { not present } \\
\text { at start of } \\
\text { study }\end{array}$ & $\begin{array}{l}\text { Compara- } \\
\text { bility of } \\
\text { cohorts }\end{array}$ & $\begin{array}{l}\text { Ascertain- } \\
\text { ment of } \\
\text { outcome }\end{array}$ & $\begin{array}{l}\text { Was } \\
\text { follow-up } \\
\text { long } \\
\text { enough for } \\
\text { outcomes } \\
\text { to occur }\end{array}$ & $\begin{array}{l}\text { Adequacy } \\
\text { of fol- } \\
\text { low-up of } \\
\text { cohorts }\end{array}$ & $\begin{array}{l}\text { Quality } \\
\text { score }\end{array}$ \\
\hline $\begin{array}{l}\text { Moyo, } \\
2007 \text { [29] }\end{array}$ & $\begin{array}{l}\text { South } \\
\text { Africa }\end{array}$ & 1 & 0 & 1 & 1 & 0 & 1 & 1 & 1 & 6 \\
\hline $\begin{array}{l}\text { Abdallah, } \\
2018 \text { [30] }\end{array}$ & Uganda & 1 & 0 & 1 & 1 & 0 & 0 & 1 & 1 & 5 \\
\hline $\begin{array}{l}\text { Elliott, } \\
2020[31]\end{array}$ & $\begin{array}{l}\text { South } \\
\text { Africa }\end{array}$ & 0 & 1 & 1 & 1 & 2 & 1 & 1 & 1 & 8 \\
\hline
\end{tabular}

*A maximum of 2 points was assigned to comparability, all others were assigned a score of 1 if the criterion was satisfied; 0-4 was considered low quality; 5-7 was considered medium quality; and 8-9 was considered high quality.

Table 2. Methodological quality scores for cross-sectional/retrospective audits*

\begin{tabular}{|c|c|c|c|c|c|c|c|c|c|}
\hline STUDY, YEAR & COUNTRY & $\begin{array}{l}\text { REPRESEN- } \\
\text { TATIVENESS } \\
\text { OF SAMPLE }\end{array}$ & $\begin{array}{l}\text { SAMPLE } \\
\text { SIZE }\end{array}$ & $\begin{array}{l}\text { NON-RE- } \\
\text { SPONDENTS }\end{array}$ & $\begin{array}{l}\text { ASCERTAIN- } \\
\text { MENT OF } \\
\text { EXPOSURE }\end{array}$ & $\begin{array}{l}\text { COMPARA- } \\
\text { BILITY }\end{array}$ & $\begin{array}{l}\text { ASSESS- } \\
\text { MENT OF } \\
\text { OUTCOME }\end{array}$ & $\begin{array}{l}\text { STATISTICAL } \\
\text { TEST }\end{array}$ & $\begin{array}{l}\text { QUALITY } \\
\text { SCORE }\end{array}$ \\
\hline Vix, 1987 [32] & Niger & 1 & 1 & 1 & 1 & 0 & 0 & 0 & 4 \\
\hline Potgieter, 1992 [33] & South Africa & 1 & 0 & 0 & 1 & 0 & 1 & 1 & 4 \\
\hline Wolf, 1996 [34] & Zimbabwe & 1 & 1 & 1 & 1 & 0 & 1 & 0 & 5 \\
\hline Kahn, 1999 [35] & South Africa & 1 & 1 & 1 & 1 & 0 & 2 & 0 & 6 \\
\hline Ibeziako, 2009 [36] & Nigeria & 1 & 1 & 1 & 1 & 2 & 2 & 1 & 9 \\
\hline duToit-Prinsloo, 2011 [37] & South Africa & 1 & 1 & 1 & 0 & 0 & 1 & 0 & 4 \\
\hline duToit-Prinsloo, 2013 [38] & South Africa & 1 & 1 & 1 & 1 & 0 & 2 & 0 & 6 \\
\hline Okpere, 2014 [39] & Nigeria & 1 & 0 & 0 & 1 & 0 & 1 & 1 & 4 \\
\hline LaGrange, 2014 [40] & South Africa & 1 & 1 & 1 & 1 & 0 & 1 & 1 & 6 \\
\hline Burger, 2014 [41] & South Africa & 1 & 1 & 1 & 1 & 0 & 1 & 1 & 6 \\
\hline Reid, 2016 [42] & South Africa & 1 & 1 & 1 & 1 & 0 & 2 & 1 & 7 \\
\hline Saayman, 2018 [43] & South Africa & 1 & 0 & 0 & 1 & 1 & 1 & 1 & 5 \\
\hline Matshazi, 2018 [44] & South Africa & 1 & 1 & 0 & 1 & 1 & 1 & 1 & 6 \\
\hline Elsobkey, 2018 [45] & Egypt & 0 & 0 & 0 & 1 & 0 & 1 & 1 & 3 \\
\hline Ikenna, 2019 [46] & Nigeria & 1 & 0 & 1 & 1 & 0 & 1 & 1 & 5 \\
\hline Bennett, 2019 [47] & South Africa & 1 & 1 & 1 & 1 & 0 & 1 & 1 & 6 \\
\hline Heathfield, 2020 [48] & South Africa & 1 & 1 & 1 & 1 & 0 & 2 & 1 & 7 \\
\hline Lapidot, 2021 [49] & Zambia & 1 & 1 & 1 & 1 & 0 & 1 & 1 & 6 \\
\hline
\end{tabular}

*A maximum of 2 points was allocated to comparability and assessment of outcome, all others were assigned 1 point if the criterion was met; 0-4 points was considered low quality; 5-7 was considered medium quality; and 8-9 was considered high quality. 
Table 3. Methodological quality scores for case reports/case series studies*

\begin{tabular}{|c|c|c|c|c|c|c|c|}
\hline STUDY, YEAR & COUNTRY & $\begin{array}{l}\text { REPRESENTATIVE- } \\
\text { NESS OF CASE(S) }\end{array}$ & $\begin{array}{c}\text { DIAGNOSIS HAS } \\
\text { BEEN CORRECTLY } \\
\text { MADE }\end{array}$ & $\begin{array}{c}\text { ALTERNATIVE } \\
\text { DIAGNOSIS HAS } \\
\text { BEEN INDICATED }\end{array}$ & $\begin{array}{c}\text { ALL IMPORTANT } \\
\text { DATA HAS BEEN } \\
\text { CITED }\end{array}$ & $\begin{array}{l}\text { OUTCOME HAS } \\
\text { BEEN CORRECTLY } \\
\text { ASCERTAINED }\end{array}$ & QUALITY SCORE \\
\hline Van Ieperen, 1983 [50] & South Africa & 1 & 0 & 0 & 1 & 1 & 3 \\
\hline Randall, 2009 [51] & South Africa & 0 & 1 & 1 & 1 & 1 & 4 \\
\hline Ker, 2010 [52] & South Africa & 1 & 1 & 1 & 1 & 1 & 5 \\
\hline Dempers, 2011 [53] & South Africa & 0 & 1 & 1 & 1 & 1 & 4 \\
\hline Dempers, 2016 [54] & South Africa & 0 & 1 & 1 & 1 & 1 & 4 \\
\hline Heathfield, 2019 [55] & South Africa & 1 & 1 & 1 & 0 & 1 & 4 \\
\hline Heathfield, 2020 [56] & South Africa & 1 & 1 & 1 & 1 & 1 & 5 \\
\hline
\end{tabular}

*Each criterion was assigned a score of 1; 0-3 was considered low quality; 4 was considered medium quality and 5 was considered high quality

Table 4. Characteristics and findings of studies focused on infant sleep practices and other maternal risk factors

\begin{tabular}{|c|c|c|c|c|c|c|c|c|}
\hline $\begin{array}{l}\text { STUDY, } \\
\text { YEAR }\end{array}$ & COUNTRY & $\begin{array}{l}\text { STUDY } \\
\text { DESIGN }\end{array}$ & $\begin{array}{l}\text { SAMPLE SIZE AND } \\
\text { POPULATION STUDIED }\end{array}$ & $\begin{array}{l}\text { Prone } \\
\text { POSITION }\end{array}$ & $\begin{array}{l}\text { SIDE } \\
\text { POSITION }\end{array}$ & $\begin{array}{l}\text { SUPINE } \\
\text { POSITION }\end{array}$ & BEDSHARING & OTHER RELEVANT FINDINGS \\
\hline $\begin{array}{l}\text { Potgieter, } \\
1992[33]\end{array}$ & $\begin{array}{l}\text { South } \\
\text { Africa }\end{array}$ & $\begin{array}{l}\text { Cross- } \\
\text { sectional } \\
\text { study }\end{array}$ & $\begin{array}{l}416 \text { mothers with } \\
\text { infants aged } 6 \mathrm{~d} \text { to } \\
6 \text { mo }\end{array}$ & $63.8 \%$ & $33.5 \%$ & $2.7 \%$ & $\begin{array}{l}60.0 \%(94.0 \% \\
\text { black, } 71.0 \% \text { col- } \\
\text { ored, } 4.0 \% \text { white }) \\
\end{array}$ & \\
\hline $\begin{array}{l}\text { Ibeziako, } \\
2009[36]\end{array}$ & Nigeria & $\begin{array}{l}\text { Cross- } \\
\text { sectional } \\
\text { study }\end{array}$ & $\begin{array}{l}480 \text { mothers with } \\
\text { infants aged } 1 \text { to } 52 \\
\text { weeks }\end{array}$ & $26.7 \%$ & $51.8 \%$ & $21.5 \%$ & $66.9 \%$ & \\
\hline & & & 282 mothers of & & & & $63.7 \%$ with mother & SIDS awareness, $35.1 \%$ \\
\hline $\begin{array}{l}\text { Okpere, } \\
2014 \text { [39] }\end{array}$ & Nigeria & $\begin{array}{l}\text { sectional } \\
\text { study }\end{array}$ & $\begin{array}{l}\text { infants aged less than } \\
1 \text { y who presented to } \\
\text { well-baby clinics }\end{array}$ & $44.3 \%$ & $20.6 \%$ & $18.1 \%$ & $\begin{array}{l}(33.5 \% \text { with both } \\
\text { parents; } 2.8 \% \text { with } \\
\text { other child) }\end{array}$ & $\begin{array}{l}81.2 \% \text { were unaware of recom- } \\
\text { mended sleep position for infants }\end{array}$ \\
\hline \multirow{3}{*}{$\begin{array}{l}\text { Burger, } \\
2014[41]\end{array}$} & \multirow{3}{*}{$\begin{array}{l}\text { South } \\
\text { Africa }\end{array}$} & \multirow{3}{*}{$\begin{array}{l}\text { Postmortem } \\
\text { retrospective } \\
\text { case audit }\end{array}$} & \multirow{3}{*}{$\begin{array}{l}82 \text { deceased infants } \\
\text { admitted as SUID } \\
\text { cases }\end{array}$} & \multirow{3}{*}{$24.0 \%$} & & & \multirow{3}{*}{$65.0 \%$} & Prematurity, $27.0 \%$ \\
\hline & & & & & & & & Parental smoking, $29.0 \%$ \\
\hline & & & & & & & & Parental alcohol use, $24.0 \%$ \\
\hline \multirow{5}{*}{$\begin{array}{l}\text { LaGrange, } \\
2014 \\
{[40] \dagger}\end{array}$} & \multirow{5}{*}{$\begin{array}{l}\text { South } \\
\text { Africa }\end{array}$} & \multirow{5}{*}{$\begin{array}{l}\text { Postmortem } \\
\text { prospective } \\
\text { descriptive } \\
\text { study }\end{array}$} & \multirow{5}{*}{$\begin{array}{l}148 \text { deceased infants } \\
\text { presenting as SUID } \\
\text { cases at Tygerberg } \\
\text { Medico-Legal Mor- } \\
\text { tuary }\end{array}$} & \multirow{5}{*}{$\begin{array}{l}30.5 \% \\
(32 / 105)\end{array}$} & & & \multirow{5}{*}{$69.5 \%(73 / 105)$} & Peak age of SUID, 1-2months \\
\hline & & & & & & & & Male vs female (60.1\% vs $39.9 \%)$ \\
\hline & & & & & & & & $\begin{array}{l}\text { Wrapped in thick heavy blankets, } \\
51.4 \%(54 / 105)\end{array}$ \\
\hline & & & & & & & & Parental smoking, 39.0\% (41/105) \\
\hline & & & & & & & & Parental alcohol use, $37.1 \%$ (39/105) \\
\hline \multirow{3}{*}{$\begin{array}{l}\text { Elsobkey*, } \\
2018[45]\end{array}$} & \multirow{3}{*}{ Egypt } & \multirow{3}{*}{$\begin{array}{l}\text { Quasi- } \\
\text { experimental } \\
\text { study }\end{array}$} & \multirow{3}{*}{$\begin{array}{l}70 \text { mothers of preterm } \\
\text { neonates with gesta- } \\
\text { tional age between } 32 \\
\text { and } 37 \text { weeks, and } \\
\text { weighing }>1500 \mathrm{~g}\end{array}$} & & & \multirow{3}{*}{$22.9 \%$} & & $\begin{array}{l}\text { SIDS awareness, } 44.3 \% \text { (Classified as } \\
\text { average to good knowledge of SIDS) }\end{array}$ \\
\hline & & & & & & & & Firm sleep surface, $40.0 \%$ \\
\hline & & & & & & & & Avoid smoke exposure, $22.9 \%$ \\
\hline \multirow{3}{*}{$\begin{array}{l}\text { Saayman, } \\
2018 \\
{[43] \dagger}\end{array}$} & \multirow{3}{*}{$\begin{array}{l}\text { South } \\
\text { Africa }\end{array}$} & \multirow{3}{*}{$\begin{array}{l}\text { Postmortem } \\
\text { descriptive } \\
\text { study }\end{array}$} & \multirow{3}{*}{$\begin{array}{l}168 \text { deceased infants } \\
\text { presenting as SUID } \\
\text { cases at Tygerberg } \\
\text { Medico-Legal Mor- } \\
\text { tuary }\end{array}$} & \multirow{3}{*}{$\begin{array}{l}23.6 \% \\
(33 / 140)\end{array}$} & \multirow{3}{*}{$\begin{array}{l}64.3 \% \\
(90 / 140)\end{array}$} & \multirow{3}{*}{$\begin{array}{l}12.1 \% \\
(17 / 140)\end{array}$} & \multirow{3}{*}{$96.0 \%(144 / 150)$} & Prenatal alcohol, 18.0\% (29/161) \\
\hline & & & & & & & & $\begin{array}{l}\text { Prenatal tobacco smoke exposure, } \\
31.0 \%(50 / 161) \text {, }\end{array}$ \\
\hline & & & & & & & & $\begin{array}{l}\text { Postnatal tobacco smoke expo- } \\
\text { sure, } 11.0 \%(15 / 136)\end{array}$ \\
\hline \multirow[b]{2}{*}{$\begin{array}{l}\text { Matshazi, } \\
2018 \\
{[44] \dagger}\end{array}$} & \multirow[b]{2}{*}{$\begin{array}{l}\text { South } \\
\text { Africa }\end{array}$} & \multirow[b]{2}{*}{$\begin{array}{l}\text { Postmortem } \\
\text { descriptive } \\
\text { study }\end{array}$} & \multirow{2}{*}{$\begin{array}{l}183 \text { deceased infants } \\
\text { aged less than } 1 \text { y ad- } \\
\text { mitted as SUID cases } \\
\text { to Tygerberg Medi- } \\
\text { co-Legal Mortuary }\end{array}$} & \multirow[b]{2}{*}{$\begin{array}{l}37.0 \% \\
(37 / 101)\end{array}$} & & & & Tobacco smoke exposure, $31.0 \%$, \\
\hline & & & & & $\begin{array}{l}53.0 \% \\
(54 / 101)\end{array}$ & $10.0 \%$ & $95.0 \%(96 / 101)$ & Prenatal alcohol use, $20.0 \%$ \\
\hline & & & & & & & & SIDS awareness, $12.2 \%$ \\
\hline & & Cross- & & & & & & Tobacco smoke exposure, $10.2 \%$ \\
\hline $2019[46]$ & Nigeria & $\begin{array}{l}\text { sectional } \\
\text { study }\end{array}$ & aged less than $1 \mathrm{y}$ & $29.4 \%$ & $45.9 \%$ & $11.7 \%$ & $91.8 \%$ & $\begin{array}{l}\text { Incidence of SUID, } 7.7 \% \text { (des- } \\
\text { cribed as mothers who witnessed } \\
\text { sudden infant death) }\end{array}$ \\
\hline & & & & & & & & Previous history of SUID, $12.8 \%$ \\
\hline & & & 1199 deceased infants & & & & & Peak age of SUID, 1-2 mo \\
\hline field, 2020 & South & retrospective & admitted as SUID & & & & $94.7 \%$ & Male vs female ( $51.7 \%$ vs $48.3 \%$ ) \\
\hline [48] & A & case audit & cases to Salt River & & & & ס & Prematurity, $40.6 \%$ \\
\hline & & & Mortuary & & & & & Tobacco smoke exposure, $53.1 \%$ \\
\hline & & & & & & & & Maternal alcohol use, $19.8 \%$ \\
\hline
\end{tabular}

y - years, mo - months

*This was a pre/post study. Prevalence estimates are baseline results

$\dagger$ Thesis/Dissertation study. 
clinic [46]. Among SUID cases, exposure to tobacco smoke was reported at a rate of $29 \%$ to $53.1 \%$ in South Africa $[40,41,43,44,48]$. Maternal use of alcohol was reported at a rate of $18 \%$ to $37.1 \%$ among SUID cases in South Africa $[40,41,43,44,48]$. One high-quality study in South Africa specifically focused on estimating the risk of SIDS in a cohort of infants due to prenatal exposure to alcohol and tobacco smoke. The study found that the adjusted relative risk for SIDS was 2.6 times higher for those who were exposed to alcohol compared to those who were not, and 3.8 times higher for those who were exposed to smoking compared to those who were not [31]. The study cohort included mothers and infants from South Africa and the US [31] It is not clear what the actual risk is in the African cohort.

\section{Infant sleep practices}

Nine of the included studies reported on infant sleep practices in Nigeria, Egypt and South Africa, either as the main outcome of the study or as secondary outcomes [33,36,39,41,43-46,48]. Four articles reported on infant sleeping practices among mothers of infants at well-baby clinics while the remainder of these articles reported on infant sleep practices among SUID cases admitted to medico-legal laboratories in South Africa. The prone sleeping position was preferred by $26.7 \%$ to $63.8 \%$ of mothers of infants at well-baby clinics $[33,36,39,46]$. The lateral sleep position was preferred by $20.6 \%$ to $51.8 \%$ of mothers $[33,36,39,46]$. Practice of the recommended supine position for infants is less common. A minority (2.7\% to $21.5 \%)$ of mothers placed their babies in the supine position during sleep $[33,36,39,46]$.

Among SUID cases, a majority of infants were reported to have been placed in the side position prior to death. The proportion of SUID cases placed to sleep in the side position was reported as 53\% to 64\% compared to $10 \%$ to $12 \%$ in the supine or back position $[43,44] .23 .6 \%$ to $37 \%$ of SUID cases were placed in the prone position $[41,43,44]$. Bedsharing was also very common. Bedsharing was reported at a rate of $60 \%$ to $91.8 \%$ among mothers of infants at well-baby clinics [33,36,39,46]. Among SUID cases, the rate was nearly 95\% [48] . One included study using post-mortem biomarkers of hypoxia did not find any significant differences between hypoxanthine and urate concentrations in vitreous humor samples of SIDS victims and infants who died of other causes [26]. Table 4 summarizes the main findings of studies focused on infant and maternal risk factors.

\section{Infectious risk factors}

Six studies explored the role of infectious agents in the pathogenesis of presumed SIDS in Africa. One medium-quality study highlighted the likely role of tuberculosis in SIDS-like deaths and found evidence of primary pulmonary tuberculosis on autopsy in a 4.5-month-old male infant whose history and death scene investigation fit the profile of a SIDS death [53]. The remaining five studies explored the role of viruses in SIDS deaths. These medium-quality studies used PCR testing to detect viral pathogens in a cohort of SIDS/SUID infants. The commonest viruses detected were HRV, RSV, HCoV, and CMV $[40,41,43,44]$. Viruses were detected in nearly half of the SIDS cases using PCR in South Africa [40]. Another medium quality study detected Coxsackie B virus in nearly 23\% of presumed SIDS cases in Tunisia [27] (Table 5).

\section{Genetic risk factors}

Five studies, all from South Africa, explored the role of genetic risk factors in SIDS/SUID cases. The earliest study is a case report from 1983 which found genetic factors to be the likely cause of death in one case of three sudden infant deaths in the same family [50]. Recently, one medium quality study found that $12.8 \%$ of mothers of SUID cases had a previous history of SUID [48] (Table 2). Pathogenic/probably pathogenic genetic variants were detected in two of these studies. One medium quality study detected pathogenic/probably pathogenic genetic variants in $20.8 \%$ of the SUID cases studied [28]. The SCN5A variant which is associated with the long QT syndrome was detected in 6.25\% of cases [28]. Another case report detected a pathogenic variant in the SCN1OA gene, a gene associated with Brugada syndrome, in a three-month-old male infant who had died of SUID [55]. Other genes and anatomic abnormalities identified in these African studies included GALT:c. $404 c>$ G, a gene associated with galactosemia [56], and left ventricular hyper-trabeculation (an anatomic defect that can lead to fatal arrhythmias) [52] (Table 5).

\section{Burden of SIDS/SUID}

Eleven studies explored the burden of SIDS/SUID in Africa. These studies provided very wide-ranging rates of SIDS in Africa, from an implausibly low rate of 0.2 per 1000 live births as reported from a study in Zimbabwe [34] to a high of 3.89 per 1000 live births in South Africa [25]. The Zimbabwean study estimated a SIDS prevalence rate of 0.2 per 1000 live births in the general population. However, we rated their statistical analyses to have a high risk of bias since the denominator for the population at risk was not the same from which 
Table 5. Characteristics and findings of studies that assessed the role of infections and genetic factors in SIDS/SUID

\begin{tabular}{|c|c|c|c|c|}
\hline STUDY, YEAR & COUNTRY & STUDY DESIGN & $\begin{array}{l}\text { SAMPLE SIZE AND } \\
\text { POPULATION STUDIED }\end{array}$ & $\begin{array}{l}\text { SIGNIFICANT } \\
\text { FACTOR }\end{array}$ \\
\hline $\begin{array}{l}\text { Dempers, } \\
2011[53]\end{array}$ & $\begin{array}{l}\text { South } \\
\text { Africa }\end{array}$ & $\begin{array}{l}\text { Case report } \\
\text { study }\end{array}$ & $\begin{array}{l}1 \text { deceased male infant aged } \\
4.5 \text { mo who died suddenly } \\
\text { and unexpectedly at a day } \\
\text { care }\end{array}$ & Primary TB \\
\hline
\end{tabular}

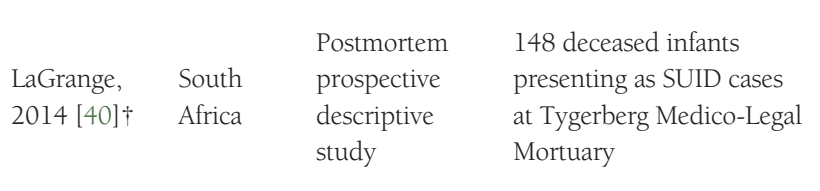

Respiratory viruses in SUID cases (HRV, RSV, HCoV, Human enterovirus, HMPV, Influenza A\&B)

\section{RELEVANT FINDINGS}

Postmortem findings were consistent with progressive primary pulmonary $\mathrm{TB}$

PCR positive HRV in 68 (46.0\%), RSV A\&B in 16 (10.8\%), HCoV in 12 (8.1\%), Human enterovirus in $6(4.1 \%)$, HMPV in $5(3.4 \%)$, PIV3 in 4 (2.7\%) and Influenza $A \& B$ in 4 (2.7\%)

(PCR positive viruses in $50.0 \%$ of SIDS cases, $74.5 \%$ in deaths classified as infection and $37.5 \%$ in deaths classified as Other) SIDS diagnosed in 33.7\% (34/101)

\begin{tabular}{|c|c|c|c|c|c|}
\hline \multirow{2}{*}{$\begin{array}{l}\text { Burger, } 2014 \\
{[41]}\end{array}$} & \multirow{2}{*}{$\begin{array}{l}\text { South } \\
\text { Africa }\end{array}$} & \multirow{2}{*}{$\begin{array}{l}\text { Postmortem } \\
\text { retrospective } \\
\text { case audit }\end{array}$} & \multirow{2}{*}{$\begin{array}{l}82 \text { deceased infants } \\
\text { admitted as SUID cases }\end{array}$} & \multirow{2}{*}{$\begin{array}{l}\text { Adenovirus, CMV } \\
\text { and RSV }\end{array}$} & $\begin{array}{l}\text { PCR positive Adenovirus in } 2(2 \%) \text {, and cytomegalo- } \\
\text { virus in } 29(35 \%) \text {. }\end{array}$ \\
\hline & & & & & RSV detected in 4 (5\%) cases using IHC \\
\hline \multirow[b]{2}{*}{$\begin{array}{l}\text { Gaaloul, } \\
2016[27]\end{array}$} & \multirow[b]{2}{*}{ Tunisia } & \multirow[b]{2}{*}{$\begin{array}{l}\text { Case-control } \\
\text { study }\end{array}$} & \multirow{2}{*}{$\begin{array}{l}56 \text { deceased infants aged } \\
2 \text { to } 11 \text { mo ( } 39 \text { SIDS cases } \\
\text { and } 17 \text { unnatural home } \\
\text { death controls) }\end{array}$} & \multirow[b]{2}{*}{ Coxsackie B virus } & PCR positive Coxsackie B virus in 9 SIDS cases ( $23.0 \%)$ \\
\hline & & & & & $\begin{array}{l}\text { (Enterovirus detected by IHC and PCR in } 6 \text { SIDS cases } \\
(15.3 \%) \text { with myocarditis and } 3(7.7 \%) \text { with peri } \\
\text { myocarditis) }\end{array}$ \\
\hline \multirow[b]{2}{*}{$\begin{array}{l}\text { Saayman, } \\
2018[43] \dagger\end{array}$} & \multirow[b]{2}{*}{$\begin{array}{l}\text { South } \\
\text { Africa }\end{array}$} & \multirow{2}{*}{$\begin{array}{l}\text { Postmortem } \\
\text { descriptive } \\
\text { study (cross- } \\
\text { sectional) }\end{array}$} & \multirow{2}{*}{$\begin{array}{l}168 \text { deceased infants } \\
\text { presenting as SUID cases } \\
\text { at Tygerberg Medico-Legal } \\
\text { Mortuary }\end{array}$} & \multirow[b]{2}{*}{ EV and B19 } & PCR positive EV and B19 in 49 cases (29\%) \\
\hline & & & & & SIDS diagnosed in $40 \%(48 / 121)$ \\
\hline \multirow[t]{2}{*}{$\begin{array}{l}\text { Matshazi, } \\
2018[44] \dagger\end{array}$} & \multirow[t]{2}{*}{$\begin{array}{l}\text { South } \\
\text { Africa }\end{array}$} & \multirow[t]{2}{*}{$\begin{array}{l}\text { Postmortem } \\
\text { descriptive } \\
\text { study (cross- } \\
\text { sectional) }\end{array}$} & \multirow[t]{2}{*}{$\begin{array}{l}183 \text { deceased infants aged } \\
\text { less than } 1 \text { y admitted as } \\
\text { SUID cases to Tygerberg } \\
\text { Medico-Legal Mortuary }\end{array}$} & \multirow[t]{2}{*}{$\begin{array}{l}\text { Respiratory viruses in } \\
\text { SUID cases }\end{array}$} & $\begin{array}{l}\text { PCR positive Human Rhinovirus A/B/C in } 65 \text { ( } 35.5 \%) \text {, } \\
\text { Adenovirus in } 18 \text { (12.6\%), Parainfluenza } 3 \text { in } 10 \\
(6.0 \%) \text {, Enterovirus in } 9(4.9 \%) \text { and RSV B in } 7(3.8 \%) \\
\text { cases }\end{array}$ \\
\hline & & & & & SIDS diagnosed in $48.3 \%(57 / 118)$ \\
\hline $\begin{array}{l}\text { Van Ieperen, } \\
1983[50]\end{array}$ & $\begin{array}{l}\text { South } \\
\text { Africa }\end{array}$ & $\begin{array}{l}\text { Case report } \\
\text { study }\end{array}$ & $\begin{array}{l}3 \text { male siblings aged } \\
6,3 \text {, and } 7 \text { weeks who } \\
\text { died suddenly and } \\
\text { unexpectedly at home } \\
\text { during sleep }\end{array}$ & $\begin{array}{l}\text { Genetic etiology: } \\
\text { Sibling history }\end{array}$ & $\begin{array}{l}\text { Postmortem findings showed possible genetic } \\
\text { abnormality in second case and rapid hypoxia probably } \\
\text { caused by smothering in third case. First case was ruled } \\
\text { as a natural death since no postmortem was performed }\end{array}$ \\
\hline $\begin{array}{l}\text { Ker, } 2010 \\
{[52]}\end{array}$ & $\begin{array}{l}\text { South } \\
\text { Africa }\end{array}$ & $\begin{array}{l}\text { Case report } \\
\text { study }\end{array}$ & $\begin{array}{l}1 \text { deceased male infant } \\
\text { aged } 3 \text { mo who presented } \\
\text { with SIDS }\end{array}$ & $\begin{array}{l}\text { Genetic etiology: } \\
\text { Cardiac disorders - } \\
\text { Left ventricular hyper } \\
\text { trabeculation }\end{array}$ & $\begin{array}{l}\text { Postmortem findings concluded that death was } \\
\text { due to fatal arrhythmia from left ventricular hyper } \\
\text { trabeculation } \\
\text { (Postmortem revealed numerous apical trabeculations } \\
\text { of left ventricle) }\end{array}$ \\
\hline \multirow[b]{2}{*}{$\begin{array}{l}\text { vanDeventer, } \\
2018[28]\end{array}$} & \multirow[b]{2}{*}{$\begin{array}{l}\text { South } \\
\text { Africa }\end{array}$} & \multirow[b]{2}{*}{$\begin{array}{l}\text { Retrospective } \\
\text { case audit } \\
\text { (genetic study) }\end{array}$} & \multirow{2}{*}{$\begin{array}{l}48 \text { FFPE tissue samples } \\
\text { from SUID cases, } 10 \\
\text { control FFPE samples } \\
\text { from deceased infants with } \\
\text { known cause of death } \\
\text { and } 9 \text { blood samples from } \\
\text { healthy volunteers }\end{array}$} & \multirow[b]{2}{*}{$\begin{array}{l}\text { Genetic etiology: } \\
\text { SCN5A }\end{array}$} & $\begin{array}{l}\text { Pathogenic/probably pathogenic genetic variants } \\
\text { detected in } 10 \text { cases }(20.8 \%)\end{array}$ \\
\hline & & & & & $\begin{array}{l}\text { SCN5A variants associated with LQTS was detected in } \\
6.2 \% \text { of cases }(3 / 48)\end{array}$ \\
\hline \multirow[t]{2}{*}{$\begin{array}{l}\text { Heathfield, } \\
2019[55]\end{array}$} & \multirow[t]{2}{*}{$\begin{array}{l}\text { South } \\
\text { Africa }\end{array}$} & \multirow[t]{2}{*}{$\begin{array}{l}\text { Case report } \\
\text { study }\end{array}$} & \multirow{2}{*}{$\begin{array}{l}1 \text { deceased male infant* } \\
\text { aged } 2 \text { mo admitted as } \\
\text { SUID }\end{array}$} & \multirow[t]{2}{*}{$\begin{array}{l}\text { Genetic etiology: } \\
\text { SCN1OA }\end{array}$} & $\begin{array}{l}\text { Rare putatively pathogenic variant was found } \\
\text { in SCN10A gene (SCN10A is linked to Brugada } \\
\text { syndrome) }\end{array}$ \\
\hline & & & & & (Infant was homozygous for this rare variant) \\
\hline \multirow{2}{*}{$\begin{array}{l}\text { Heathfield, } \\
2020[56]\end{array}$} & \multirow{2}{*}{$\begin{array}{l}\text { South } \\
\text { Africa }\end{array}$} & \multirow{2}{*}{$\begin{array}{l}\text { Case report } \\
\text { study }\end{array}$} & \multirow{2}{*}{$\begin{array}{l}1 \text { deceased female infant* } \\
\text { aged } 3 \text { mo }\end{array}$} & \multirow{2}{*}{$\begin{array}{l}\text { Genetic etiology: } \\
\text { GALT: c. } 404 C>G\end{array}$} & $\begin{array}{l}\text { Genetic testing found that infant was homozygous for } \\
\text { GALT: c. } 404 \mathrm{C}>\mathrm{G}\end{array}$ \\
\hline & & & & & $\begin{array}{l}\text { (Estimated prevalence: } 1 \text { infant out of } 102 \text { black African } \\
\text { SUID cases) }\end{array}$ \\
\hline
\end{tabular}

$\mathrm{y}$ - years, mo - months

HCoV - human coronavirus, HRV - human rhinovirus, EV - enterovirus, CMV - cytomegalovirus, RSV - respiratory syncytial virus, B19 - parvovirus B19, HMPV - human metapneumovirus, PIV3 - parainfluenza virus type 3, IHC - Immunohistochemistry, PCR - polymerase chain reaction, FFPE - formalin fixed, paraffin-embedded (FFPE), SCN5A - sodium voltage-gated channel alpha subunit 5, SCN10A - sodium voltage-gated channel alpha subunit 10, LQTS - long QT syndrome, GALT - galactose-1-phosphate uridylyl transferase, TB - tuberculosis

*Infant was of African ancestry.

$\uparrow$ Thesis/Dissertation study. 
the infants with apparent SIDS were sampled. In addition, one study from Niger reported a SIDS prevalence rate of 2.5 per 1000 live births in healthy infants and 40 per 1000 live births in infants with sickle cell disease [32]. We also rated this study as low quality since there was a high risk of bias in the statistical analysis.

The South African studies provided relatively stronger estimates of the SIDS prevalence rate in the general population. The earliest estimate of SIDS prevalence in South Africa was in 1989 when one medium-quality study reported a SIDS prevalence rate of 3.01 per 1000 live births [25]. Recently, one high-quality prospective cohort study reported an unadjusted risk of SIDS in a cohort of infants in Cape Town as 3.7 per 1000 live births [31]. Among deceased infants, SIDS accounted for between 2.5\% to 21\% of infant deaths in South Africa $[37,38,42,54]$. However, very few studies outside of South Africa provided estimates on the proportion of infant deaths due to SIDS. One medium-quality study from Zambia estimated that $11.3 \%$ of infant deaths were due to suspected SIDS [49] (Table 6).

\section{Diagnostic challenges}

Two studies reported on the challenge of making a diagnosis of SIDS. One medium-quality study from South Africa reported on the inadequacy of death scene investigation in SUID cases in South Africa. They noted that only $59.2 \%$ of SUID cases had a complete death scene investigation [47]. To account for the uncertainty posed by an asphyxia risk in making an accurate diagnosis of SIDS, study authors in another medium-quality study incorporated asphyxia in a new classification schema for SUID cases. They found that this classification schema performed well in assigning the cause of death compared to the standard classification schema [51] (Table 6).

Table 6. Characteristics and findings of studies on the burden of SIDS/SUID and diagnostic challenges in Africa

\begin{tabular}{|c|c|c|c|c|c|}
\hline $\begin{array}{l}\text { STUDY, } \\
\text { YEAR }\end{array}$ & COUNTRY & STUDY DESIGN & $\begin{array}{l}\text { SAMPLE SIZE AND } \\
\text { POPULATION STUDIED }\end{array}$ & SIGNIFICANT FACTOR & RELEVANT FINDINGS \\
\hline $\begin{array}{l}\text { Vix, } 1987 \\
{[32]}\end{array}$ & Niger & $\begin{array}{l}\text { Cross-sectional } \\
\text { study }\end{array}$ & $\begin{array}{l}400 \text { mothers of infants at } \\
\text { well-baby clinics }\end{array}$ & SIDS & $\begin{array}{l}\text { SIDS prevalence per } 1000 \text { live births: } 2.5 \text { in healthy } \\
\text { infants. } 40 \text { in sickle cell infants }\end{array}$ \\
\hline $\begin{array}{l}\text { Molteno, } \\
1989[25]\end{array}$ & $\begin{array}{l}\text { South } \\
\text { Africa }\end{array}$ & $\begin{array}{l}\text { Case-control } \\
\text { study }\end{array}$ & $\begin{array}{l}299 \text { children aged } 1 \text { mo } \\
\text { to } 5 \text { y ( } 199 \text { cases and } 100 \\
\text { healthy controls) }\end{array}$ & $\begin{array}{l}\text { SIDS, other causes of } \\
\text { early childhood death: } \\
\text { deaths determined } \\
\text { at birth and deaths } \\
\text { from accidents and } \\
\text { acquired disease }\end{array}$ & $\begin{array}{l}\text { SIDS incidence per } 1000 \text { live births: } 3.89 \text { overall, } 3.05 \\
\text { if obvious cause of death is removed at autopsy (White } \\
1.05 \text { and Colored } 3.41 \text { ) }\end{array}$ \\
\hline $\begin{array}{l}\text { Wolf, } 1996 \\
{[34]}\end{array}$ & Zimbabwe & $\begin{array}{l}\text { Postmortem } \\
\text { prospective } \\
\text { descriptive study }\end{array}$ & $\begin{array}{l}180 \text { deceased infants aged } \\
1 \text { mo to } 1 \mathrm{y} \text { who died at } \\
\text { home }\end{array}$ & SIDS & $\begin{array}{l}\text { SIDS incidence per } 1000 \text { live births: } 0.20 \text { ( } 95 \% \text { CI: } \\
0.004-0.4 \text { ) [ } 4 \text { cases out of } 18889 \text { live births] }\end{array}$ \\
\hline $\begin{array}{l}\text { Kahn, } \\
1999[35]\end{array}$ & $\begin{array}{l}\text { South } \\
\text { Africa }\end{array}$ & $\begin{array}{l}\text { Cross-sectio- } \\
\text { nal study (De- } \\
\text { mographic } \\
\text { and health } \\
\text { surveillance) }\end{array}$ & 216 children under 5 y & SIDS & 2 SIDS deaths (Number of infants aged $<1$ y is unclear) \\
\hline \multirow[b]{2}{*}{$\begin{array}{l}\text { Moyo, } \\
2007 \text { [29] }\end{array}$} & \multirow[b]{2}{*}{$\begin{array}{l}\text { South } \\
\text { Africa }\end{array}$} & \multirow[b]{2}{*}{$\begin{array}{l}\text { Prospective } \\
\text { cohort study }\end{array}$} & \multirow{2}{*}{$\begin{array}{l}11677 \text { children enrolled } \\
\text { in a Tuberculosis vaccine } \\
\text { field trial }\end{array}$} & \multirow[b]{2}{*}{ SUID } & SUID prevalence per 1000 live births: 1.03 per 1000 \\
\hline & & & & & $\begin{array}{l}\text { SUID prevalence among deceased infants } 8.2 \% \\
(12 / 146)\end{array}$ \\
\hline $\begin{array}{l}\text { duToit- } \\
\text { Prinsloo, } \\
2011[37]\end{array}$ & $\begin{array}{l}\text { South } \\
\text { Africa }\end{array}$ & $\begin{array}{l}\text { Retrospective case } \\
\text { audit }\end{array}$ & $\begin{array}{l}813 \text { deceased infants } \\
\text { younger than } 1 \text { y of age } \\
\text { that were admitted to the } \\
\text { medico-legal mortuaries } \\
\text { of Pretoria and Tygerberg }\end{array}$ & SIDS & $\begin{array}{l}\text { SIDS prevalence among deceased infants } 21.0 \% \\
(171 / 813)\end{array}$ \\
\hline $\begin{array}{l}\text { duToit- } \\
\text { Prinsloo, } \\
2013[38]\end{array}$ & $\begin{array}{l}\text { South } \\
\text { Africa }\end{array}$ & $\begin{array}{l}\text { Retrospective case } \\
\text { audit }\end{array}$ & $\begin{array}{l}2583 \text { deceased infants } \\
\text { younger than } 1 \text { y of age } \\
\text { that were admitted to } 5 \\
\text { academic medico-legal } \\
\text { centers across } 4 \text { provinces } \\
\text { in South Africa }\end{array}$ & SUID & $\begin{array}{l}\text { SIDS prevalence among deceased infants } 8.7 \% \\
(224 / 2583)\end{array}$ \\
\hline $\begin{array}{l}\text { Reid, } 2016 \\
{[42]}\end{array}$ & $\begin{array}{l}\text { South } \\
\text { Africa }\end{array}$ & $\begin{array}{l}\text { Retrospective case } \\
\text { audit }\end{array}$ & $\begin{array}{l}700 \text { deceased children } \\
\text { aged less than } 5 \text { y in the } \\
\text { Metro West geographical } \\
\text { area of the Western Cape } \\
\text { Province in South Africa }\end{array}$ & Under-5 mortality & SIDS prevalence among deceased infants $2.5 \%$ (14/564) \\
\hline
\end{tabular}


Table 6. continued

\begin{tabular}{|c|c|c|c|c|c|}
\hline $\begin{array}{l}\text { STUDY, } \\
\text { YEAR }\end{array}$ & COUNTRY & TUDY DESIGN & $\begin{array}{l}\text { SAMPLE SIZE AND } \\
\text { POPULATION STUDIED }\end{array}$ & SIGNIFICANT FACTOR & RELEVANT FINDINGS \\
\hline $\begin{array}{l}\text { Dempers, } \\
2016[54]\end{array}$ & $\begin{array}{l}\text { South } \\
\text { Africa }\end{array}$ & Case series & $\begin{array}{l}18 \text { deceased infants } \\
\text { admitted as SUID cases }\end{array}$ & SIDS & $\begin{array}{l}\text { SIDS prevalence among deceased infants 38\% (7/18) } \\
\text { based on } 1990 \text { NICHD schema }\end{array}$ \\
\hline \multirow{2}{*}{$\begin{array}{l}\text { Abdallah, } \\
2018[30]\end{array}$} & \multirow[b]{2}{*}{ Uganda } & \multirow{2}{*}{$\begin{array}{l}\text { Prospective } \\
\text { cohort study }\end{array}$} & \multirow{2}{*}{$\begin{array}{l}164 \text { preterm infants with } \\
\text { birth weight less than or } \\
\text { equal to } 1500 \mathrm{~g}\end{array}$} & \multirow{2}{*}{$\begin{array}{l}\text { Cause of mortality in } \\
\text { preterm infants }\end{array}$} & Suspected cot death $4.9 \%(8 / 164)$ \\
\hline & & & & & SIDS prevalence among deceased infants $25.0 \%(8 / 32)$ \\
\hline \multirow{6}{*}{$\begin{array}{l}\text { Elliott, } \\
2020[31]\end{array}$} & \multirow{6}{*}{$\begin{array}{l}\text { South } \\
\text { Africa }\end{array}$} & \multirow{6}{*}{$\begin{array}{l}\text { Prospective } \\
\text { cohort study }\end{array}$} & \multirow{6}{*}{$\begin{array}{l}10088 \text { pregnant women } \\
\text { in two residential areas } \\
\text { within Cape Town South } \\
\text { Africa and five areas in } \\
\text { the United States; } 6240 \\
\text { infants from the South } \\
\text { African site }\end{array}$} & \multirow{6}{*}{ SIDS } & SIDS incidence per 1000 live births: \\
\hline & & & & & 3.70 per 1000 live births (unadjusted) \\
\hline & & & & & Adjusted relative risk of SIDS: Alcohol 2.59 (95\% \\
\hline & & & & & $\mathrm{CI}=1.14-5.90, P=0.024) ;$ Smoking $3.84(95 \%$ \\
\hline & & & & & $\mathrm{CI}=1.42-10.42, P=0.008)$ \\
\hline & & & & & one/quit early) \\
\hline $\begin{array}{l}\text { Lapidot, } \\
2021[49]\end{array}$ & Zambia & $\begin{array}{l}\text { Postmortem } \\
\text { prospective } \\
\text { descriptive study }\end{array}$ & $\begin{array}{l}230 \text { deceased infants aged } \\
4 \mathrm{~d} \text { to } 6 \mathrm{mo}\end{array}$ & SUID & $\begin{array}{l}\text { SUID prevalence among deceased infants } 11.3 \% \\
(26 / 230)\end{array}$ \\
\hline $\begin{array}{l}\text { Belonje, } \\
1996[26]\end{array}$ & $\begin{array}{l}\text { South } \\
\text { Africa }\end{array}$ & $\begin{array}{l}\text { Case-control } \\
\text { study }\end{array}$ & $\begin{array}{l}84 \text { infants aged less than } \\
1 \text { y } 50 \text { SIDS cases and } \\
34 \text { controls who died of } \\
\text { other causes }\end{array}$ & $\begin{array}{l}\text { Hypoxanthine and } \\
\text { Urate as biomarkers } \\
\text { of SIDS }\end{array}$ & $\begin{array}{l}\text { No difference in hypoxanthine concentration between } \\
\text { SIDS victims and other causes of death ( } P \text { value of } \\
\text { difference in mean concentration of Hypoxanthine at } 1 \text {, } \\
2,3,4 \text { and } 5 \text { postmortem interval days is } 0.862,0.014 \text {, } \\
0.331,0.424 \text { and } 0.508 \text { respectively) }\end{array}$ \\
\hline $\begin{array}{l}\text { Randall, } \\
2009 \text { [51] }\end{array}$ & $\begin{array}{l}\text { South } \\
\text { Africa }\end{array}$ & Case series study & $\begin{array}{l}10 \text { deceased infants, } \\
\text { median age } 2 \text { mo } \\
\text { admitted as SUID cases }\end{array}$ & Classification schema & $\begin{array}{l}\text { SIDS was diagnosed in } 6 \text { infants using standard } \\
\text { classification schema compared to } 2 \text { infants using new } \\
\text { classification schema }\end{array}$ \\
\hline \multirow{2}{*}{$\begin{array}{l}\text { Bennett, } \\
2019 \text { [47] }\end{array}$} & \multirow{2}{*}{$\begin{array}{l}\text { South } \\
\text { Africa }\end{array}$} & \multirow{2}{*}{$\begin{array}{l}\text { Retrospective case } \\
\text { audit }\end{array}$} & \multirow{2}{*}{$\begin{array}{l}454 \text { deceased infants } \\
\text { admitted as SUID cases }\end{array}$} & \multirow{2}{*}{$\begin{array}{l}\text { Death scene } \\
\text { investigation practices }\end{array}$} & $\begin{array}{l}\text { Proportion of SUID cases with death scene investigation } \\
59.2 \%\end{array}$ \\
\hline & & & & & Proportion of infant deaths due to SUID 6.6\% (454/6922) \\
\hline
\end{tabular}

$\mathrm{y}$ - years, mo - months

\section{DISCUSSION}

Our main conclusions are that, with the singular exception of studies from South Africa, there is a paucity of information about the risk factors for or burden of SIDS in Africa. Overall, this supports our initial concerns that SIDS in Africa has historically been a very low priority for the global health community, except for a recent set of publications. And yet there is no reason to believe that SIDS would not be a major cause of infant mortality in Africa as it has proven to be wherever else SIDS has been studied. In support of this argument, our review found a high burden of SIDS/SUID and high rates of known risk factors of SIDS in Africa. The rates of the prone and side sleeping positions in this review are much higher than the rates reported from other countries such as the US and the UK. In the UK, the prone sleeping position has remained relatively stable at a rate of $23 \%$ to $24 \%$ in recent years [57]. In the US, $7.8 \%$ of mothers reported placing their infants to sleep in the prone position in a study of 3297 mothers [58]. Additionally, the CDC reported that $21.9 \%$ of mothers placed their infants to sleep in a non-supine position in 2015 [59]. In Brazil, findings from the 2015 Pelotas Birth Cohort study estimated that less than $2 \%$ of mothers placed their infants in the prone sleeping position [60]. The American Academy of Pediatrics (AAP) recommends that infants be placed in the supine position to sleep. The AAP further recommends that infants do not share the same sleep surface with their caregivers [5]. It is worrying that very few infants are placed in the recommended supine/back position to sleep in this review. The reported rates of $2.7 \%$ to $21.5 \%$ are much lower than the rates reported elsewhere ( $77 \%$ in the US) [58]. The side or prone sleeping position poses a risk of rebreathing expired gases which can lead to hypoxia or hypercapnia [7]. The results of one included study did not support the view that pre-mortem hypoxia is a common feature in SIDS when compared with other causes of death [26]. However, the validity of this forensic tool in the evaluation of SIDS has recently been called into question [61].

The rates of bedsharing of $60 \%$ to $91.8 \%$ in this review are also much higher than the rates reported from the US and Australia. In the US, it is estimated that $20.7 \%$ to $24.4 \%$ of mothers reported bedsharing with their infants [59,62]. In Australia, a study by Cunningham et al. revealed a 44.7\% bedsharing rate among 2745 mothers in Victoria [63]. Since bedsharing and prone or side sleeping appear to be highly prevalent in the African studies in our review, there appears to be a significant unexplored opportunity to reduce infant mortality in these settings. 
Previous studies have established prematurity as a risk factor of SIDS [64-66]. Findings from this review suggest a high risk of SIDS for preterm infants in Africa. Almost half of the SUID cases in South Africa were preterm. Moreover, SIDS was the leading cause of death among a cohort of preterm infants in Uganda. These findings are consistent with results from developed countries. Malloy in 2013 showed that despite the decline in SIDS rates among term infants, the risk of SIDS among the preterm remained high [66]. We also found high rates of maternal smoking and alcohol use among mothers of infants with SUID in South Africa. For instance, almost half of the SUID cases in South Africa were exposed to tobacco smoke either through the mother or another person in the household, and more than a quarter of these mothers reported using alcohol [48]. The reported rates of tobacco smoke exposure to infants in this review are also higher than the rates reported elsewhere. Using linked birth and infant death data from 2007 to 2011, one large study in the US reported that 8.9\% of mothers smoked during pregnancy [67] compared to the 10.2\% found in this review [46].

Infectious agents and genetic factors have been suggested as likely causes in the pathogenesis of SIDS [8,9]. There is evidence to suggest that viral agents play a role in the pathogenesis of SIDS either directly or indirectly through interactions with bacteria [68]. Previous studies have suggested that $80 \%$ of SIDS cases report a mild upper respiratory tract infection in the days prior to death $[8,68]$. Respiratory viruses were detected in nearly half of the SIDS/SUID cases in this review, lending credence to the possible role of respiratory viruses in the pathogenesis of SIDS. In addition, genetic testing detected pathogenic/probably pathogenic genetic variants in nearly $21 \%$ of SUID cases in one included study and a pathogenic variant of the SCN5A gene in $6.25 \%$ of SIDS cases in another included study in this review. Our findings are consistent with prior research by Weese-Mayer et al. who estimated that between 5\% to 10\% of SIDS cases had novel mutations in the SCN5A gene leading to the long QT syndrome [69]. These studies confirm the need for more detailed investigations to fully identify the cause of death in SIDS/SUID cases. Given the low rates of genetic testing in Africa, these causes of infant mortality are likely going undetected. Whether this represents another opportunity to reduce infant mortality in Africa is very unclear, however. Prospective screening has failed to be effective in high-income settings, making it hard to argue for operationalizing this ineffective strategy in a low-resource setting. They however highlight that these lesser-known risk factors of SIDS are likely present in Africa.

Findings from this review also indicate that Africa likely has some of the highest rates of SIDS in the world. Relying on methodological quality, the most recent estimate from South Africa indicates a SIDS rate of 3.7 per 1000 live births [31]. This rate is significantly higher than current estimates from the UK (0.3 per 1000 live births)[57], US (0.3 per 1000)[70], Australia (SUID rate 0.5 per 1000), Germany (0.53 SUID rate per 1000) and Japan (0.6 SUID rate per 1000) [6]. Collectively, these studies suggest that SIDS probably accounts for a larger share of infant deaths in Africa than has generally been appreciated. Given the high rates of prone/lateral sleeping position and bedsharing in this review, more studies conducted outside of South Africa may find the SIDS burden across Africa is actually even higher.

Ultimately, SIDS is a diagnosis of exclusion and can only be diagnosed when other causes of death have been ruled out following death scene and detailed post-mortem investigations. Most countries in Africa lack the resources to conduct a proper SIDS investigation. Even South Africa, which is sort of a pioneer in SIDS investigations, lags other well-developed economies. Moreover, distinguishing between SIDS and suffocation deaths due to an unsafe sleep environment can be challenging. This challenge is emphasized when one considers that infants who may have a genetic predisposition to SIDS may only experience SIDS in the setting of an additional proximal factor, such as sleep position, bedding composition, or swaddling practices.

\section{Strengths and limitations}

The main strength of this review is that this is the first systematic review on SIDS in Africa. To our knowledge, no other review has been conducted on SIDS/SUID using studies from Africa. Our study is not without limitations. The majority of the included studies were conducted in South Africa which may affect the generalizability of our findings to the entire continent. However, most of the South African studies were conducted on predominantly Black or bi-racial populations and thus results can be extrapolated to other similar populations in the continent.

\section{CONCLUSIONS}

National campaigns to promote a safe sleep environment are lacking in Africa. The "back to sleep" campaign in the UK for instance led to a $40 \%$ decline in the SIDS rate in the first year alone [57]. Similar declines were noted in the US following the implementation of safe sleep campaigns [71]. These campaigns target some of 
the major risk factors of SIDS, such as prone sleeping and bedsharing [57], and would be worthwhile in Africa to tackle the high infant mortality rates. However, the paucity of high-quality studies outside of South Africa limits our ability to make recommendations for such campaigns. Future research should focus on prospectively estimating the prevalence of SIDS in countries other than South Africa.

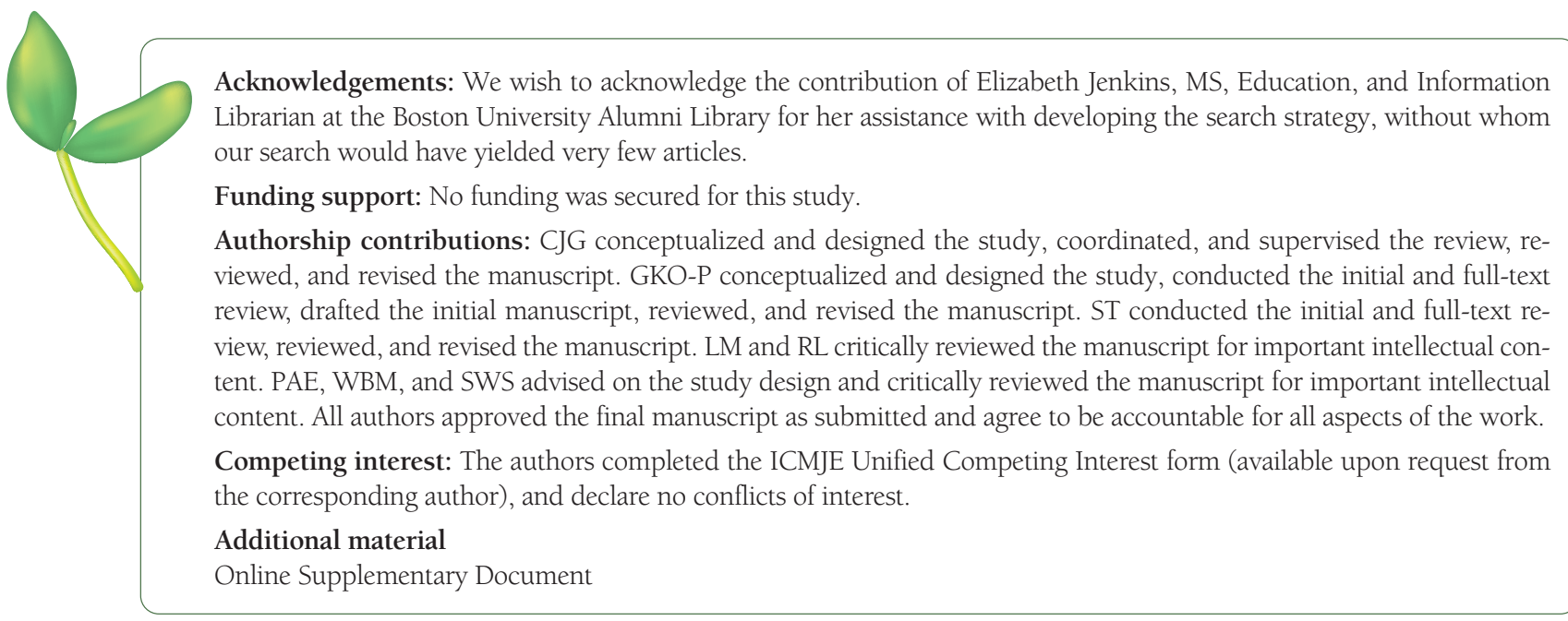

1 Centers for Disease Control and Prevention (CDC). Infant Mortality | Maternal and Infant Health | Reproductive Health | CDC. 2019. Available: https://www.cdc.gov/reproductivehealth/maternalinfanthealth/infantmortality.htm. Accessed: 28 May 2020.

2 Willinger M, James LS, Catz C. Defining the Sudden Infant Death Syndrome (Sids): Deliberations of an Expert Panel Convened by the National Institute of Child Health and Human Development. Pediatr Pathol. 1991;11:677-84. doi:10.3109/15513819109065465. Medline:1745639

3 Beckwith JB. Defining the Sudden Infant Death Syndrome. Arch Pediatr Adolesc Med. 2003;157:286-90. Medline:12622679 doi:10.1001/archpedi.157.3.286

4 About SIDS and SUID | CDC. 2020. Available: https://www.cdc.gov/sids/about/index.htm. Accessed: 28 May 2020.

5 Moon RY. TASK FORCE ON SUDDEN INFANT DEATH SYNDROME. SIDS and Other Sleep-Related Infant Deaths: Evidence Base for 2016 Updated Recommendations for a Safe Infant Sleeping Environment. Pediatrics. 2016;138:e20162940. Medline:27940805 doi:10.1542/peds.2016-2940

6 Duncan JR, Byard RW, editors. SIDS Sudden Infant and Early Childhood Death: The Past, the Present and the Future. Adelaide (AU): University of Adelaide Press; 2018. Available: http://www.ncbi.nlm.nih.gov/books/NBK513384/. Accessed: 9 August 2021.

7 Kanetake J, Aoki Y, Funayama M. Evaluation of rebreathing potential on bedding for infant use. Pediatr Int. 2003;45:284-9. Medline:12828582 doi:10.1046/j.1442-200X.2003.01708.x

8 Alfelali M, Khandaker G. Infectious causes of sudden infant death syndrome. Paediatr Respir Rev. 2014;15:307-11. Medline:25441371 doi:10.1016/j.prrv.2014.09.004

9 Neubauer J, Lecca MR, Russo G, Bartsch C, Medeiros-Domingo A, Berger W, et al. Post-mortem whole-exome analysis in a large sudden infant death syndrome cohort with a focus on cardiovascular and metabolic genetic diseases. Eur J Hum Genet. 2017;25:404-9. Medline:28074886 doi:10.1038/ejhg.2016.199

10 Øyen N, Skjaerven R, Irgens LM. Population-based Recurrence Risk of Sudden Infant Death Syndrome Compared with Other Infant and Fetal Deaths. Am J Epidemiol. 1996;144:300-5. Medline:8686699 doi:10.1093/oxfordjournals.aje.a008925

11 Daltveit AK, Irgens LM, Oyen N, Skjaerven R, Markestad T, Alm B, et al. Sociodemographic risk factors for sudden infant death syndrome: associations with other risk factors. The Nordic Epidemiological SIDS Study. Acta Paediatr. 1998;87:28490. Medline: 9560035

12 O'Leary CM, Jacoby PJ, Bartu A, D’Antoine H, Bower C. Maternal Alcohol Use and Sudden Infant Death Syndrome and Infant Mortality Excluding SIDS. Pediatrics. 2013;131:e770-8. Medline:23439895 doi:10.1542/peds.2012-1907

13 Mitchell EA, Milerad J. Smoking and the sudden infant death syndrome. Rev Environ Health. 2006;21:81-103. Medline:16898673 doi:10.1515/REVEH.2006.21.2.81

14 Jonville-Béra A-P, Autret-Leca E, Barbeillon F, Paris-Llado J. Sudden unexpected death in infants under 3 months of age and vaccination status - a case-control study. Br J Clin Pharmacol. 2001;51:271-6. Medline:11298074 doi:10.1046/j.13652125.2001.00341.x

15 Dempers JJ, Burger EH, Toit-Prinsloo LD, Verster J. A South African Perspective. In: Duncan JR, Byard RW, editors. SIDS Sudden Infant and Early Childhood Death: The Past, the Present and the Future. Adelaide (AU): University of Adelaide Press; 2018. Available: http://www.ncbi.nlm.nih.gov/books/NBK513389/. Accessed: 28 May 2020.

16 Ndu IK. Sudden infant death syndrome: an unrecognized killer in developing countries. Pediatric Health Med Ther. 2016;7:14. Medline:29388586 doi:10.2147/PHMT.S99685 
17 Gilbert R, Salanti G, Harden M, See S. Infant sleeping position and the sudden infant death syndrome: systematic review of observational studies and historical review of recommendations from 1940 to 2002. Int J Epidemiol. 2005;34:874-87. Medline:15843394 doi:10.1093/ije/dyi088

18 Pienaar E, Grobler L, Busgeeth K, Eisinga A, Siegfried N. Developing a geographic search filter to identify randomised controlled trials in Africa: finding the optimal balance between sensitivity and precision. Health Info Libr J. 2011;28:210-5. Medline:21831220 doi:10.1111/j.1471-1842.2011.00936.x

19 Wells G, Shea B, O'Connel D, Peterson J, Welch V, Losos M, et al. The Newcastle-Ottawa Scale (NOS) for assessing the quality of nonrandomised studies in meta-analyses. 2020. Available: http://www.ohri.ca/programs/clinical_epidemiology/oxford. asp. Accessed: 8 June 2021

20 Haffar S, Bazerbachi F, Garg S, Lake JR, Freeman ML. Frequency and prognosis of acute pancreatitis associated with acute hepatitis E: A systematic review. Pancreatology. 2015;15:321-6. Medline:26049260 doi:10.1016/j.pan.2015.05.460

21 Bazerbachi F, Leise MD, Watt KD, Murad MH, Prokop LJ, Haffar S. Systematic review of mixed cryoglobulinemia associated with hepatitis E virus infection: association or causation? Gastroenterol Rep (Oxf). 2017;5:178-84. Medline:28852522 doi:10.1093/gastro/gox021

22 Bazerbachi F, Haffar S, Szarka LA, Wang Z, Prokop LJ, Murad MH, et al. Secretory diarrhea and hypokalemia associated with colonic pseudo-obstruction: A case study and systematic analysis of the literature. Neurogastroenterol Motil. 2017;29. Medline:28580600 doi:10.1111/nmo.13120

23 Herzog R, Álvarez-Pasquin MJ, Díaz C, Del Barrio JL, Estrada JM, Gil Á. Are healthcare workers' intentions to vaccinate related to their knowledge, beliefs and attitudes? a systematic review. BMC Public Health. 2013;13:154. Medline:23421987 doi:10.1186/1471-2458-13-154

24 Page MJ, McKenzie JE, Bossuyt PM, Boutron I, Hoffmann TC, Mulrow CD, et al. The PRISMA 2020 statement: an updated guideline for reporting systematic reviews. BMJ. 2021;372. Medline:33782057

25 Molteno CD, Ress E, Kibel MA. Early childhood mortality in Cape Town. S Afr Med J. 1989;75:570-4. Medline:2727857

26 Belonje PC, Wilson GR, Siroka SA. High postmortem concentrations of hypoxanthine and urate in the vitreous humor of infants are not confined to cases of sudden infant death syndrome. S Afr Med J. 1996;86:827-8. Medline:8764909

27 Gaaloul I, Riabi S, Evans M, Hunter T, Huber S, Aouni M. Postmortem diagnosis of infectious heart diseases: A mystifying cause of Sudden Infant Death. Forensic Sci Int. 2016;262:166-72. Medline:27016640 doi:10.1016/j.forsciint.2016.03.002

28 van Deventer BS, du Toit-Prinsloo L, van Niekerk C. Feasibility of analysis of the SCN5A gene in paraffin embedded samples in sudden infant death cases at the Pretoria Medico-Legal Laboratory, South Africa. Forensic Sci Med Pathol. 2018;14:276-84. Medline:29907895 doi:10.1007/s12024-018-9995-5

29 Moyo S, Hawkridge T, Mahomed H, Workman L, Minnies D, Geiter LJ, et al. Determining causes of mortality in children enrolled in a vaccine field trial in a rural area in the Western Cape Province of South Africa. J Paediatr Child Health. 2007;43:17883. Medline:17316193 doi:10.1111/j.1440-1754.2007.01039.x

30 Abdallah Y, Namiiro F, Nankunda J, Mugalu J, Vaucher Y. Mortality among very low birth weight infants after hospital discharge in a low resource setting. BMC Pediatr. 2018;18:239. Medline:30031387 doi:10.1186/s12887-018-1226-4

31 Elliott AJ, Kinney HC, Haynes RL, Dempers JD, Wright C, Fifer WP, et al. Concurrent prenatal drinking and smoking increases risk for SIDS: Safe Passage Study report. EClinicalMedicine. 2020;19:100247. Medline:32140668 doi:10.1016/j eclinm.2019.100247

32 Vix J, Buguet A, Straboni S, Beidari H. Sudden infant death and sickle cell anemia in the Sahel region of Africa. Med Trop (Mars). 1987;47:153-9. Medline:3626817

33 Potgieter ST, Kibel MA. Sleeping positions of infants in the Cape Peninsula. S Afr Med J. 1992;81:355-7. Medline:1561557

34 Wolf BH, Ikeogu MO. Is sudden infant death syndrome a problem in Zimbabwe? Ann Trop Paediatr. 1996;16:149-53. Medline:8790679 doi:10.1080/02724936.1996.11747818

35 Kahn K, Tollman SM, Garenne M, Gear JSS. Who dies from what? Determining cause of death in South Africa's rural northeast. Trop Med Int Health. 1999;4:433-41. Medline:10444319 doi:10.1046/j.1365-3156.1999.00415.x

36 Ibeziako NS, Ibekwe RC, Ibe BC. Infant sleeping environment in South-eastern Nigeria (sleeping place and sleeping position): a preliminary survey. J Trop Med. 2009;2009:283046. Medline:20309418 doi:10.1155/2009/283046

37 du Toit-Prinsloo L, Dempers JJ, Wadee SA, Saayman G. The medico-legal investigation of sudden, unexpected and/or unexplained infant deaths in South Africa: where are we-and where are we going? Forensic Sci Med Pathol. 2011;7:14-20. Medline:20652450 doi:10.1007/s12024-010-9184-7

38 du Toit-Prinsloo L, Dempers J, Verster J, Hattingh C, Nel H, Brandt VD, et al. Toward a standardized investigation protocol in sudden unexpected deaths in infancy in South Africa: a multicenter study of medico-legal investigation procedures and outcomes. Forensic Sci Med Pathol. 2013;9:344-50. Medline:23564060 doi:10.1007/s12024-013-9427-5

39 Okpere AN, Opara PI. Mothers' knowledge and practice of infant sleep position. Niger J Paediatr. 2014;41:312-5. doi:10.4314/ njp.v4li4.4

40 La Grange H. Respiratory pathogens in cases of Sudden Unexpected Death in Infancy (SUDI) at Tygerberg forensic pathology service mortuary. Stellenbosch: Stellenbosch University; 2014.

41 Burger MC, Dempers JJ, de Beer C. Profiling the approach to the investigation of viral infections in cases of sudden unexpected death in infancy in the Western Cape Province, South Africa. Forensic Sci Int. 2014;239:27-30. Medline:24727219 doi:10.1016/j.forsciint.2014.03.007

42 Reid AE, Hendricks MK, Groenewald P, Bradshaw D. Where do children die and what are the causes? Under-5 deaths in the Metro West geographical service area of the Western Cape, South Africa, 2011. S Afr Med J. 2016;106:51. Medline:27032849 doi:10.7196/SAMJ.2016.v106i4.10521 
43 Saayman JE. Profiling Enterovirus and Parvovirus B19 in sudden and unexpected death in infancy (SUDI) at the Tygerberg Medico-legal Mortuary and the role of myocarditis as a possible cause of death. Stellenbosch: Stellenbosch University; 2018.

44 Matshazi DM. Respiratory infections and immune biomarkers of infection and inflammation in cases of Sudden Unexpected Death in Infancy (SUDI) at the Tygerberg Medico-Legal Mortuary. Stellenbosch: Stellenbosch University; 2018.

45 Elsobkey FA. Mothers' Health Education based on Health Belief Model to Promote Health of Preterm Infant Related to Sudden Infant Death Syndrome. Am J Nurs. 2018;6:164-73. doi:10.12691/ajnr-6-4-4

46 Ikenna NK, Osita EU, Benedict EO, Nnamdi OF, Ndagubam OC, Isaac AN, et al. Awareness of sudden infant death syndrome and choice of infant's sleep position among mothers in Enugu, Southeast Nigeria. Indian J Child Health (Bhopal). 2019;6:3704. doi:10.32677/IJCH.2019.v06.i07.010

47 Bennett T, Martin LJ, Heathfield LJ. A retrospective study of death scene investigation practices for sudden unexpected death of infants (SUDI) in Cape Town, South Africa. Forensic Sci Med Pathol. 2020;16:49-56. Medline:31808133

48 Heathfield LJ, Martin LJ, Ramesar R. A 5-year retrospective analysis of infant death at Salt River Mortuary, Cape Town. South Afr J Child Health. 2020;14:148-54. doi:10.7196/SAJCH.2020.v14i3.01720

49 Lapidot R, Williams AL, MacLeod WB, Mwale M, Olowojesiku R, Enslen A, et al. Verbal Autopsies for Out-of-Hospital Infant Deaths in Zambia. Pediatrics. 2021;147:e20201767. Medline:33664096 doi:10.1542/peds.2020-1767

50 Van Ieperen L. Three cot deaths in one family. A case report. S Afr Med J. 1983;63:1019-20. Medline:6857437

51 Randall BB, Wadee SA, Sens MA, Kinney HC, Folkerth RD, Odendaal HJ, et al. A practical classification schema incorporating consideration of possible asphyxia in cases of sudden unexpected infant death. Forensic Sci Med Pathol. 2009;5:254-60. Medline:19484508 doi:10.1007/s12024-009-9083-y

52 Ker J, Toit-Prinsloo LD, van Heerden WFP, Saayman G. Sudden infant death syndrome and left ventricular hypertrabeculation-hidden arrhythmogenic entity? Clin Med Insights Cardiol. 2010;4:85-7. Medline:20981130 doi:10.4137/CMC.S5933

53 Dempers J, Sens MA, Wadee SA, Kinney HC, Odendaal HJ, Wright CA. Progressive primary pulmonary tuberculosis presenting as the sudden unexpected death in infancy: a case report. Forensic Sci Int. 2011;206:e27-30. Medline:20705406 doi:10.1016/j. forsciint.2010.07.018

54 Dempers JJ, Coldrey J, Burger EH, Thompson V, Wadee SA, Odendaal HJ, et al. The Institution of a Standardized Investigation Protocol for Sudden Infant Death in the Eastern Metropole, Cape Town, South Africa. J Forensic Sci. 2016;61:1508-14. Medline:27677096 doi:10.1111/1556-4029.13204

55 Heathfield LJ, Martin LJ, Ramesar R. Massively parallel sequencing in sudden unexpected death in infants: A case report in South Africa. Forensic Sci International Genet Suppl Ser. 2019;7:459-61. doi:10.1016/j.fsigss.2019.10.051

56 Heathfield LJ, Bhengu W, Louw S, Martin LJ, Ramesar R. Assessment of candidate variants causative of inborn metabolic diseases in SUDI cases in South Africa, and a case report. Int J Legal Med. 2020;134:1639-45. Medline:32556492 doi:10.1007/ s00414-020-02337-6

57 Garstang J, Pease AS. A United Kingdom Perspective. In: Duncan JR, Byard RW, editors. SIDS Sudden Infant and Early Childhood Death: The Past, the Present and the Future. Adelaide (AU): University of Adelaide Press; 2018.

58 Colson ER, Geller NL, Heeren T, Corwin MJ. Factors Associated With Choice of Infant Sleep Position. Pediatrics. 2017;140:e20170596. Medline:28827382 doi:10.1542/peds.2017-0596

59 Bombard JM. Vital Signs: Trends and Disparities in Infant Safe Sleep Practices — United States, 2009-2015. MMWR Morb Mortal Wkly Rep. 2018;67:39-46. Medline:29324729 doi:10.15585/mmwr.mm6701el

60 da Silva BGC, da Silveira MF, de Oliveira PD, Domingues MR, Neumann NA, Barros FC, et al. Prevalence and associated factors of supine sleep position in 3-month-old infants: findings from the 2015 Pelotas (Brazil) Birth Cohort. BMC Pediatr. 2019;19:165. Medline:31126263 doi:10.1186/s12887-019-1534-3

61 Madea B, Rödig A. Time of death dependent criteria in vitreous humor: accuracy of estimating the time since death. Forensic Sci Int. 2006;164:87-92. Medline:16439082 doi:10.1016/j.forsciint.2005.12.002

62 Smith LA, Geller NL, Kellams AL, Colson ER, Rybin DV, Heeren T, et al. Infant Sleep Location and Breastfeeding Practices in the United States, 2011-2014. Acad Pediatr. 2016;16:540-9. Medline:26851615 doi:10.1016/j.acap.2016.01.021

63 Cunningham HM, Vally H, Bugeja L. Bed-Sharing in the First 8 Weeks of Life: An Australian Study. Matern Child Health J. 2018;22:556-64. Medline:29299793 doi:10.1007/s10995-017-2424-7

64 Malloy MH, Hoffman HJ. Prematurity, sudden infant death syndrome, and age of death. Pediatrics. 1995;96:464-71. Medline:7651779

65 Ostfeld BM, Schwartz-Soicher O, Reichman NE, Teitler JO, Hegyi T. Prematurity and Sudden Unexpected Infant Deaths in the United States. Pediatrics. 2017;140:e20163334. Medline:28759397 doi:10.1542/peds.2016-3334

66 Malloy MH. Prematurity and sudden infant death syndrome: United States 2005-2007. J Perinatol. 2013;33:470-5. Medline:23288251 doi:10.1038/jp.2012.158

67 Anderson TM, Ferres JML, Ren SY, Moon RY, Goldstein RD, Ramirez J-M, et al. Maternal Smoking Before and During Pregnancy and the Risk of Sudden Unexpected Infant Death. Pediatrics. 2019;143:e20183325. Medline:30858347 doi:10.1542/ peds.2018-3325

68 Highet AR. An infectious aetiology of sudden infant death syndrome. J Appl Microbiol. 2008;105:625-35. Medline:18266695 doi:10.1111/j.1365-2672.2008.03747.x

69 Weese-Mayer DE, Ackerman MJ, Marazita ML, Berry-Kravis EM. Sudden Infant Death Syndrome: review of implicated genetic factors. Am J Med Genet A. 2007;143A:771-88. Medline:17340630 doi:10.1002/ajmg.a.31722

70 Centers for Disease Control and Prevention (CDC). Data and Statistics for SIDS and SUID I CDC. 2021. Available: https://www. cdc.gov/sids/data.htm. Accessed: 23 June 2021.

71 Willinger M, Hoffman HJ, Wu KT, Hou JR, Kessler RC, Ward SL, et al. Factors associated with the transition to nonprone sleep positions of infants in the United States: the National Infant Sleep Position Study. JAMA. 1998;280:329-35. Medline:9686549 doi:10.1001/jama.280.4.329 